\title{
INCREASING THE BIOLOGICAL RESISTANCE OF GYPSUM BY MEANS OF SILVER, CALCIUM AND COPPER IONS
}

\author{
ZdenĚK ProšeK ${ }^{a, b, *}$, Hana Sekavová $^{a}$, Pavla Ryparováa $^{a}$ \\ ${ }^{a}$ Czech Technical University in Prague, Faculty of Civil Engineering, Department of Mechanics, Thákurova 7, \\ 16629 Prague 6, Czech Republic \\ ${ }^{b}$ Czech Technical University in Prague, University Centre for Energy Efficient Buildings, Třinecká 1024, 273 \\ 43 Buštěhrad, Czech Republic \\ * corresponding author: zdenek.prosek@fsv.cvut.cz
}

\begin{abstract}
The article focuses on the effects of additives increasing biological resistance of gypsum against degradation of the material. In this study we use silver nitrate, calcium oxide and copper sulphate as an additive that improves biological resistance of gypsum composites. The amount of addition was calculated so that the amount of ions was $0.1,0.3$ and $0.5 \mathrm{wt}$. \%. Microbial degradation was determined as the degree of resistance of materials to the occurrence of bacteria and molds by optical and electron microscope. The results obtained from these samples were compared with references materials created in the laboratory and available on today's market. The results show a positive effect of silver and copper ions on the bioresistance of gypsum.
\end{abstract}

KEYWORDS: Biological resistance, calcium oxide, copper sulphate, gypsum, silver nitrate.

\section{INTRODUCTION}

Gypsum is a widely used material in construction, especially for the production of gypsum plaster, wallboard, gypsum blocks [1]. Gypsum is one of the longest used binders, it was already known in Egypt or Assyria. It has been used in Europe since the early Middle Ages [2]. Gypsum composites are more environmentally friendly and production is faster than cement composites. Mainly due to lower greenhouse gas emissions and sustainability [3]. Gypsum is produced by thermal decomposition of $\mathrm{CaSO}_{4} \cdot 2 \mathrm{H}_{2} \mathrm{O}$ in a so-called boiling process at $130-150{ }^{\circ} \mathrm{C}$ [4]. The material for the production of gypsum can be natural or also waste after flue gas desulphurisation from thermal power plants (industry gypsum).

The use of gypsum composites in construction is significantly limited because they have low resistance to damage of moisture. The moisture content of the material adversely affects the formation of bacteria, molds and the multiplication of other microorganisms [5]. Molds are microorganisms that commonly occur on the inner and outer surfaces of building materials and can cause sick building syndrome, which limits or completely restrict the use of the building [6]. For this reason, it is very important to create biological resistance materials that resist the formation of mold on their surface and inside the material.

One of the ways to increase the biological resistance of gypsum is to prevent the access of water or moisture. Without the presence of water, mold and bacteria colonies cannot form. Reduced water absorption is achieved by the use of hydrophobic additives such as waxes [7], saponifiers [8] and emulsifiers [9]. This method of protecting gypsum is very effective, but prevents possible future recycling of gypsum. During recycling, the hydrophobicizing additive cannot be separated from the gypsum and thus the calcined gypsum can no longer be mixed properly with the water and thus prevents it from solidifying properly [10]. Another option is to create an environment that does not allow the growth of molds and bacteria. For example, it is a very alkaline environment that restricts the growth of bacteria and molds [11]. The last possibility to improve the biological resistance of gypsum composites is by adding antibacterial components (such as silver [12], titanium dioxide [13], copper [14]).

This article deals with the direct use of silver and copper ions as additives that increase biological resistance. When penicillin was discovered, silver and other biocidal materials were almost abandoned. But today, with the emergence of antibiotic-resistant strains, it has gained new interest [15]. Silver has been reported in several studies $[16,17]$ as an effective bactericidal antibacterial agent. Gypsum composite with antibacterial components is also being developed and investigated [5], but some of its properties are still unknown. In an experimental study, the effect of silver ions on the mechanical properties of the gypsum composite was investigated and it was found that: the introduction of silver ions results in a less compact structure of hardened gypsum samples, leading to a $20 \%$ deterioration in flexural strength [18]. Work dealing with other additives is completely missing.

\section{MAterials AND SAMPLES}

In our study of gypsum biodegradation, three reference materials were used: Ref 1 was labora- 


\begin{tabular}{ccccc}
\hline Set & Gypsum $[\mathbf{g}]$ & Admixtures & Water $[\mathrm{g}]$ & Ions and their content \\
\hline Ref 1 & 500 & - & 320 & - \\
$\mathrm{Ag} 0.1$ & 500 & $\mathrm{AgNO}_{3}-1.33 \mathrm{~g}$ & 320 & $\mathrm{Ag}-0.1$ wt. $\%$ \\
$\mathrm{Ag} 0.3$ & 500 & $\mathrm{AgNO}_{3}-4.02 \mathrm{~g}$ & 320 & $\mathrm{Ag}-0.3$ wt. $\%$ \\
$\mathrm{Ag} 0.5$ & 500 & $\mathrm{AgNO}_{3}-6.69 \mathrm{~g}$ & 320 & $\mathrm{Ag}-0.5$ wt. $\%$ \\
$\mathrm{Ca} 0.1$ & 500 & $\mathrm{CaO}-1.19 \mathrm{~g}$ & 320 & $\mathrm{Ca}-0.1$ wt. $\%$ \\
$\mathrm{Ca} 0.3$ & 500 & $\mathrm{CaO}-3.57 \mathrm{~g}$ & 320 & $\mathrm{Ca}-0.3$ wt. $\%$ \\
$\mathrm{Ca} 0.5$ & 500 & $\mathrm{CaO}-5.94 \mathrm{~g}$ & 320 & $\mathrm{Ca}-0.5$ wt. $\%$ \\
$\mathrm{Cu} 0.1$ & 500 & $\mathrm{CuSO}_{4}-2.14 \mathrm{~g}$ & 320 & $\mathrm{Cu}-0.1$ wt. $\%$ \\
$\mathrm{Cu} 0.3$ & 500 & $\mathrm{CuSO}_{4}-6.41 \mathrm{~g}$ & 320 & $\mathrm{Cu}-0.3$ wt. $\%$ \\
$\mathrm{Cu} 0.5$ & 500 & $\mathrm{CuSO}_{4}-10.68 \mathrm{~g}$ & 320 & $\mathrm{Cu}-0.5$ wt. $\%$ \\
\hline
\end{tabular}

TABle 1. Composition of tested sets.

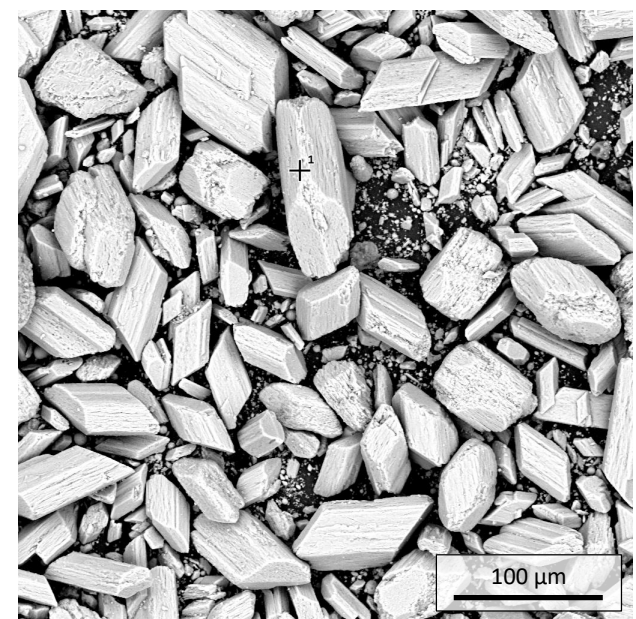

FiguRE 1. Image from electron microscope, BSE detector, magnified $400 \times$.

tory produced according to Table 1, Ref 2 is made of gypsum slurry for plasterboards (marked H2) designation with reduced water absorption and thus higher bioresistance, according to the standard ČSN EN $520+$ A1 [19] and Ref 3 is made of gypsum slurry for plasterboards marked A (common use), according to standard ČSN EN 520 + A1 [19]. Ref. 2 and 3 were used to compare with current materials on today's market.

The resistance to biodegradation of the laboratory mixture was increased by ions of silver, calcium and copper. Silver ions were obtained from the addition of silver nitrate $\left(\mathrm{AgNO}_{3}\right)$, calcium ions from calcium oxide $(\mathrm{CaO})$ and copper ions from copper sulphate $\left(\mathrm{CuSO}_{4}\right)$. The amount of addition was calculated so that the amount of ions was $0.1,0.3$ and 0.5 wt. \% (Table 1). Silver and copper ions were chosen because of their biocidal properties and calcium due to increased alkalinity of the environment which prevents the growth of molds and bacteria. Five samples were made from each set according to Table 1 . The samples were stored for 9 days in a laboratory environment at temperature $22 \pm 3{ }^{\circ} \mathrm{C}$ and relative humidity $50 \pm 5 \%$. Subsequently, the samples were tested.

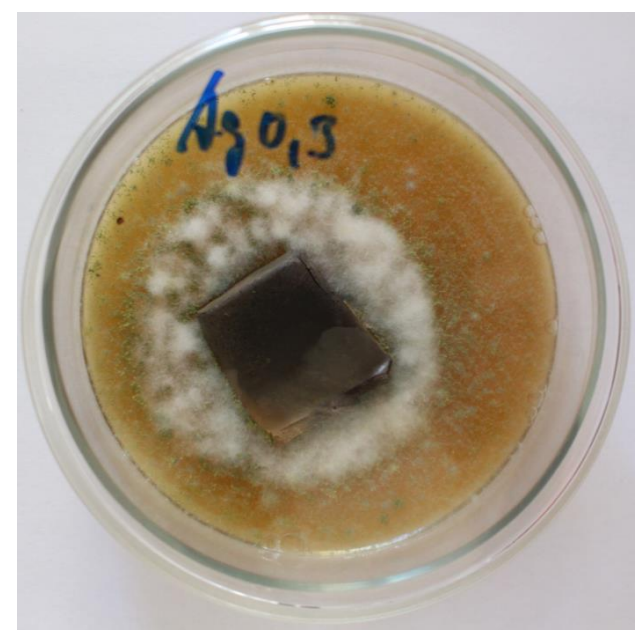

Figure 2. Sample placed on agar in petri dish after 41 days.

In all cases, gypsum from the Knauf Praha company was used, originating from the industry gypsum of the Počerady power plant. Figure 1 show the typical character of gypsum grains, which are composed of only one phase and have an elongated, onesided oriented shape. The results of the EDS analysis show that the gypsum grain is composed of calcium 19 wt. $\%$, sulfur 17 wt. $\%$ and oxygen 64 wt. \%. When converted to atomic percent and using stoichiometry, it can be stated that it is pure gypsum.

\section{EXPERIMENTAL METHODS}

Microbial degradation was performed according to the standard ISO EN 846 [20], which determines the degree of resistance of materials to the occurrence of molds or determines their resistance to biodegradation. The produced samples had a size of $1 \times$ $1 \times 1 \mathrm{~cm}$. Sterilization was performed using UV radiation, which damaged microorganisms from the surface while maintaining the material and chemical parameters of individual samples. Other types of possible sterilization, apart from radioactivity, degrade the original properties of the materials and were therefore not used. Samples were inoculated with a 


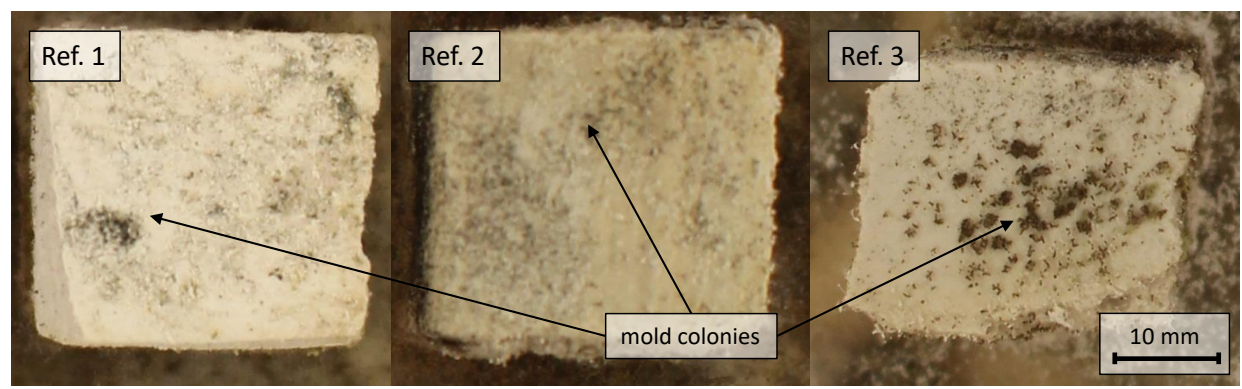

FiguRE 3. Surface of reference samples after 41 days of exposure to molds and bacteria.

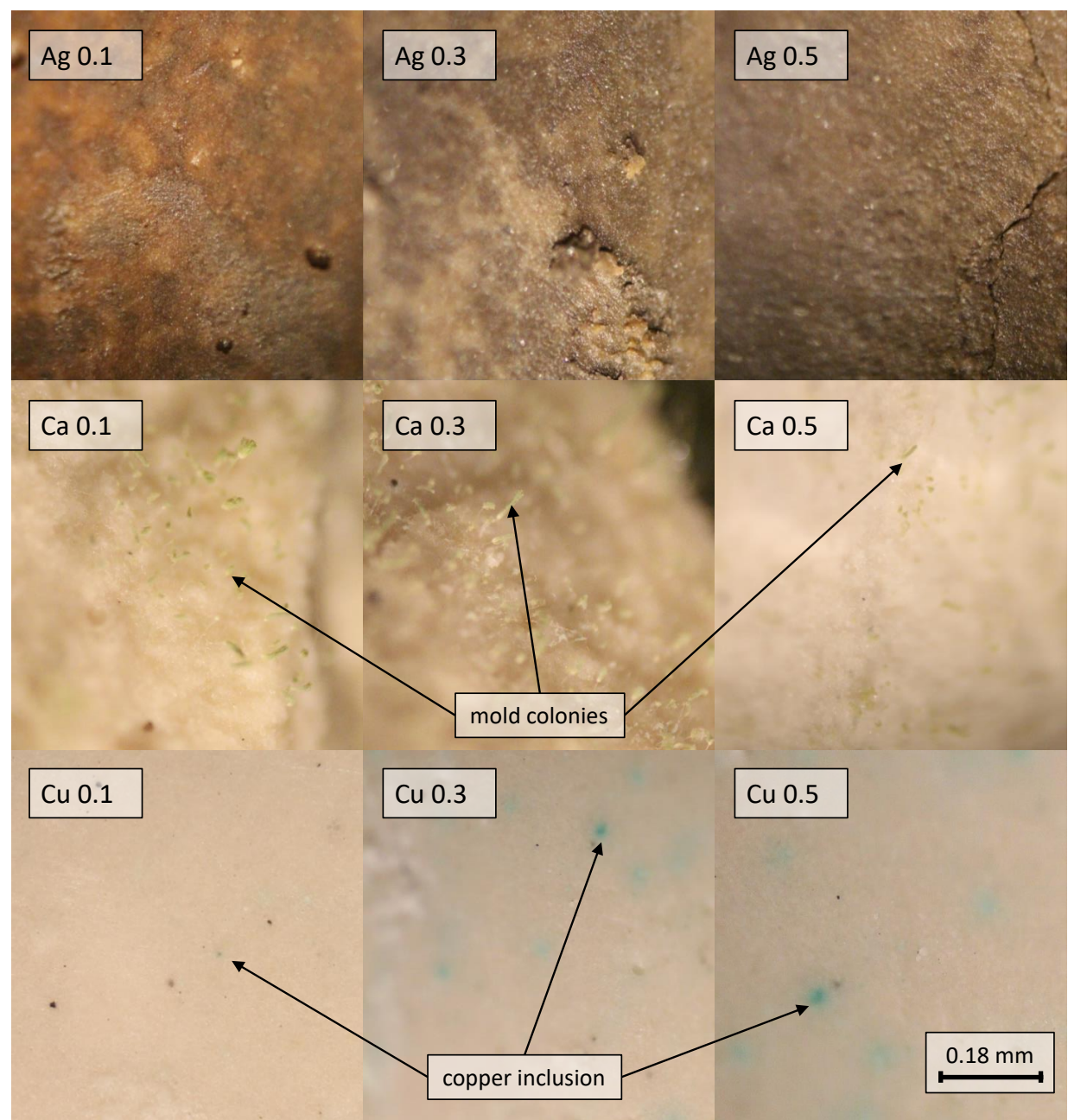

Figure 4. Optical microscope images of tested materials. magnified $120 \times$.

consortium of molds and then plated on agar (Czapek Dox) at $25 \pm 3{ }^{\circ} \mathrm{C}$ and monitored for 41 days (Fig. 2). The consortium of molds contained microorganisms from the Czech Collection of Microorganisms: Paecilomyces variotti, Chaetomyum globosum, Penicillium funiculosum, Aspergillus terreus, Penicillium brevicompactum. The resistance of the materials was evaluated visually and monitored by optical microscope.

Optical microscopy was performed using a zoom microscope with 3D imaging capabilities. This is a device from ZEISS Axio Zoom.V16. Clusters of ad- ditive ions were discovered during optical microscopy. For this reason, optical microscopy has been supplemented by electron microscopy. A scanning electron microscope with a Schottky cathode FEG SEM Merlin ZEISS was used for electron microscopy, which is located in the Laboratory of Electron Microscopy and Micro-analysis at the University Center for Energy Efficient Buildings in Buštěhrad. Quantitative and qualitative analysis of the chemical composition of the samples was performed by X-ray microanalysis directly with an energy dispersive spectrometer (EDS) from Oxford Instruments. During the anal- 

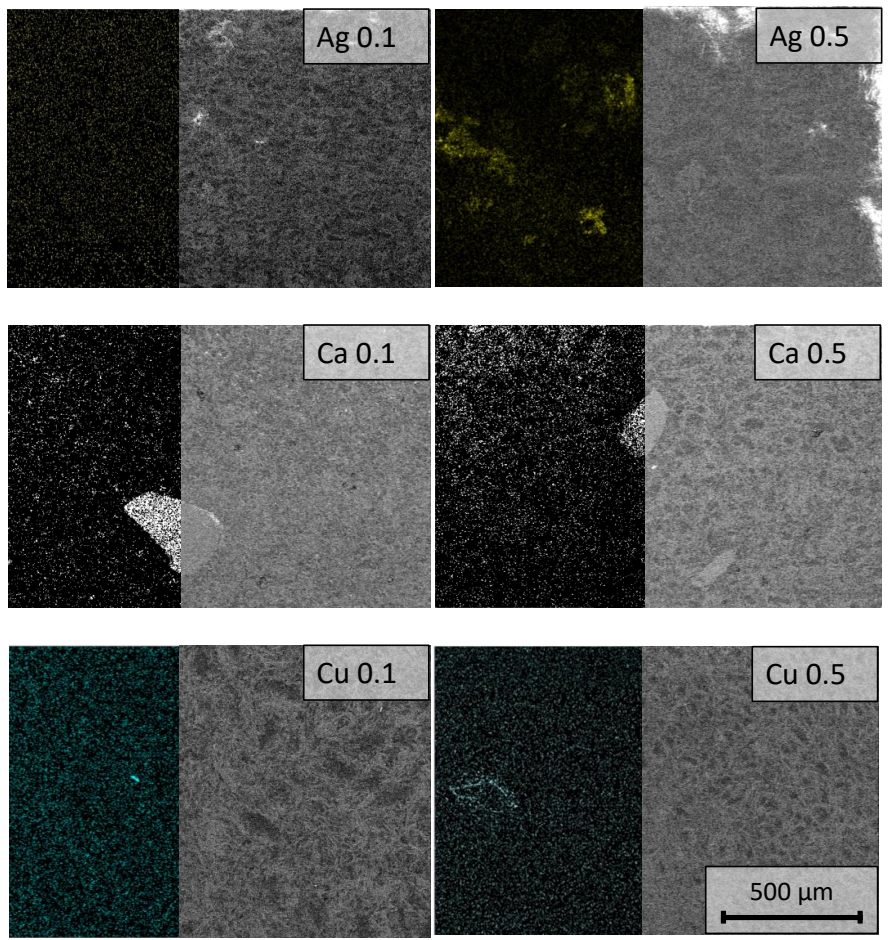

FigURE 5. Image from electron microscope, BSE detector, magnified $200 \times$ with EDS element maps (yellow - silver, white - calcium and blue - copper).

ysis, the microscope settings were as follows: accelerating voltage $20 \mathrm{kV}$, current $2 \mathrm{nA}$, resolution $1024 \mathrm{px}$, work distance $8.5 \mathrm{~mm}$ and acquisition time $60 \mathrm{~s}$. Due to the higher electric current required for elemental analysis, $3 \mathrm{~nm}$ of platinum were sputtering on surface of samples.

\section{Results AND Discussion}

Figure 3 shows a comparison of reference materials. The Ref. 3 sample had almost the entire sides covered, and mold colonies were already present on the surface on day 22 . The coverage rate did not change much at the end of the experiment, but the molds began to fructify. Samples Ref. 1 and 2 had similar results and were generally resistant to the occurrence of molds, after 41 days only isolated colonies of molds were visible on the surface, the sides of the samples were only partially covered, approximately $40 \%$. The laboratory mixture Ref. 1 achieved the same results as gypsum slurry with lower water absorption (Ref. 2) due to the fact that it did not contain paper pulp and other materials contained in gypsum slurry for plasterboards which reduces bio-resistance.

In the case of added ions, all variants were highly resistant to biodegradation. For this reason, optical microscopy was performed. Figure 4 shows the surfaces of the tested materials by optical microscope. The results show a positive effect of copper and silver, where after 41 days no microorganisms formed on the surface of the materials. In the case of calcium ions, a mold colony can be found on the surface of all materials tested. Silver and copper ions $100 \%$ increase the bioresistance of gypsum even in the lowest tested amount of ions. In addition, it can be seen that with a higher concentration of copper ions, clusters occur.

The individual ion clusters can be seen in Figure 5 from electron microscopy. The images were taken using a BSE detector and show the phase contrast. In addition, the left part of the images is supplemented by an element map, where elements were selected for individual ions. Silver is shown in yellow, calcium in white and copper in blue. The results show that higher concentrations $(0.5$ wt. \%) of silver and copper ions form clusters. In the case of a concentration of 0.1 wt. $\%$, the ions are homogeneously distributed throughout the structure. Individual $\mathrm{CaO}$ grains can be seen in the calcium sample ( $\mathrm{Ca} 0.1$ and $\mathrm{Ca}$ 0.5).

The results of the influence of silver and copper ions are in agreement with other authors who have used applications for other building materials such as lime and lime-cement plasters [21]. The formation of clusters explains the decreasing mechanical properties of gypsum with a high content of silver ions, which are described by other authors [18].

\section{CONCLUSiOnS}

This work was focused on the influence of different type of admixtures on biological resistance of gypsum. The researched samples were composed of gypsum from Knauf Praha (Počerady) and various types of biocidal material. Silver, calcium and copper ions in three different concentrations $(0.1,0.3$ and 0.5 wt. \%) 
were used as biocidal material. Based on the results, it can be concluded that:

- The addition of silver, calcium and copper ions has increased the resistance to gypsum biodegradation and the materials are comparable to those on the market today.

- Higher ion concentration (0.5 wt. \%) form clumps and inhomogeneity of materials.

- Silver and copper ions were most effective, where no colony of molds and bacteria formed after 41 days for all ion concentrations.

Future research will focus on finding a minimum concentration of silver ions in gypsum that will be resistant to biodegradation. Next research will not deal with calcium ions, due to lower efficiency and copper ions, due to toxicity and current legislation [22].

\section{ACKNOWLEDGEMENTS}

This paper was financially supported by the TA CR research a project under the number TJ02000235 and by Czech Technical University in Prague under No. SGS project SGS19/148/OHK1/3T/11. The authors also thank Knauf, Praha Ltd. for the supplied samples and materials and the Center for Nanotechnology in Civil Engineering at the Faculty of Civil Engineering, Czech Technical University in Prague.

\section{REFERENCES}

[1] M. Doleželová, A. Vimmrová. Moisture influence on compressive strength of ternary gypsum-based binders. In AIP Conference proceedings, vol. 1863, p. 290003. AIP Publishing LLC, 2017. DOI:10.1063/1.4992440.

[2] J. Oster. Gypsum usage in irrigated agriculture: a review. Fertilizer research 3(1):73-89, 1982. DOI:10.1007/BF01063410.

[3] N. Lushnikova, L. Dvorkin. Sustainability of gypsum products as a construction material. In Sustainability of Construction Materials, pp. 643-681. Elsevier, 2016. DOI:10.1016/B-978-0-08-100370-1.00025-1.

[4] A. Vimmrová, M. Doleželová, R. Černý. Ternární směsi na bázi sádry se zlepšenými mechanickými vlastnostmi. Stavební obzor Praha: Fakulta stavební $\check{C} V U T$ 7(8), 2014.

[5] J. Krejsová, M. Doleželová. Resistance of mortars with gypsum, lime and composite binders against molds. Acta Polytechnica CTU Proceedings 21:16-20, 2019. DOI:10.14311/APP.2019.21.0016.

[6] A. Ghaffarianhoseini, H. AlWaer, H. Omrany, et al. Sick building syndrome: are we doing enough? Architectural Science Review 61(3):99-121, 2018. DOI:10.1080/00038628.2018.1461060.

[7] G. Mumford, R. W. Phillips. Dimensional change in wax patterns during setting of gypsum investments. Journal of Dental Research 37(2):351-358, 1958. DOI:10.1177/00220345580370022301.

[8] M. Razali, M. Aziz, W. Hamdan, et al. Synthesis of grease from waste oils and red gypsum. Australian Journal of Basic and Applied Sciences 11:154-159, 2017.
[9] Y. Zhang, K. Wang, W. Tao, D. Li. Preparation of microencapsulated phase change materials used graphene oxide to improve thermal stability and its incorporation in gypsum materials. Construction and Building Materials 224:48-56, 2019. DOI:10.1016/j.conbuildmat.2019.06.227.

[10] H. Sekavová, J. Herrmann, Z. Prošek, et al. The influence of the use of recycled gypsum on the properties of gypsum products in labor conditions. Acta Polytechnica CTU Proceedings 26:81-85, 2020. DOI:10.14311/APP.2020.26.0081.

[11] M. Ono, K. Yamaguchi, N. Yamaguchi. Antimicrobial compositions comprising hop acid alkali salts and uses thereof, 2007. US Patent App. 11/731,764.

[12] M. Rai, A. Yadav, A. Gade. Silver nanoparticles as a new generation of antimicrobials. Biotechnology advances 27(1):76-83, 2009. DOI:10.1016/j.biotechadv.2008.09.002.

[13] A. M. Allahverdiyev, E. S. Abamor, M. Bagirova, M. Rafailovich. Antimicrobial effects of tio2 and ag2o nanoparticles against drug-resistant bacteria and leishmania parasites. Future microbiology 6(8):933-940, 2011. DOI:10.2217/fmb.11.78.

[14] G. Ren, D. Hu, E. W. Cheng, et al. Characterisation of copper oxide nanoparticles for antimicrobial applications. International journal of antimicrobial agents 33(6):587-590, 2009. DOI:10.1016/j.ijantimicag.2008.12.004.

[15] I. Chopra. The increasing use of silver-based products as antimicrobial agents: a useful development or a cause for concern? Journal of antimicrobial Chemotherapy 59(4):587-590, 2007. DOI:10.1093/jac/dkm006.

[16] G. da Silva, E. Guidelli, G. de Queiroz-Fernandes, et al. Silver nanoparticles in building materials for environment protection against microorganisms. International Journal of Environmental Science and Technology 16(3):1239-1248, 2019. DOI:10.1007/s13762-018-1773-0.

[17] Q. Qiang, N. Hongwei, X. Wei, et al. Antibacterial mechanism of silver. Journal of Wuhan University of Science and Technology (Natural Science Edition) 2, 2007.

[18] Z. Prošek, P. Tesárek. Effects of additives increasing biological resistance of gypsum on mechanical properties of resulting composite. In Experimental Stress Analysis - 58th International Scientific Conference, EAN 2020 Conference Proceedings. in press, 2020.

[19] ČSN EN 520+A1. Sádrokartonové desky - definice, požadavky a zkušební metody. Praha: Úřad pro technickou normalizaci, metrologii a státní zkušebnictví

[20] ČSN EN ISO 846. Plasty - Hodnocení působení mikroorganismů. Praha: Úřad pro technickou normalizaci, metrologii a státní zkušebnictví 2019.

[21] A. Jerónimo, A. Camões, B. Aguiar, N. Lima. Hydraulic lime mortars with antifungal properties. Applied Surface Science 483:1192-1198, 2019. DOI:10.1016/j.apsusc.2019.03.156.

[22] N. A. Ashford, C. C. Caldart. Environmental law, policy, and economics: Reclaiming the environmental agenda. Mit Press, 2008. 